\title{
LEVEL II SCOUR ANALYSIS FOR BRIDGE 51 (BRIDTH00460051) on TOWN HIGHWAY 46, crossing OTTAUQUECHEE RIVER, BRIDGEWATER, VERMONT
}

U.S. Geological Survey Open-File Report 96-242

Prepared in cooperation with

VERMONT AGENCY OF TRANSPORTATION and

FEDERAL HIGHWAY ADMINISTRATION 


\section{LEVEL II SCOUR ANALYSIS FOR BRIDGE 51 (BRIDTH00460051) on TOWN HIGHWAY 46, crossing OTTAUQUECHEE RIVER, BRIDGEWATER, VERMONT}

By SCOTT A. OLSON and MICHAEL A. IVANOFF

U.S. Geological Survey Open-File Report 96-242

Prepared in cooperation with

VERMONT AGENCY OF TRANSPORTATION and

FEDERAL HIGHWAY ADMINISTRATION 


\title{
U.S. DEPARTMENT OF THE INTERIOR BRUCE BABBITT, Secretary
}

\author{
U.S. GEOLOGICAL SURVEY \\ Gordon P. Eaton, Director
}

For additional information write to:

District Chief

U.S. Geological Survey 361 Commerce Way

Pembroke, NH 03275
Copies of this report may be purchased from:

U.S. Geological Survey Earth Science Information Center Open-File Reports Section Box 25286, MS 517 Federal Center

Denver, CO 80225 


\section{CONTENTS}

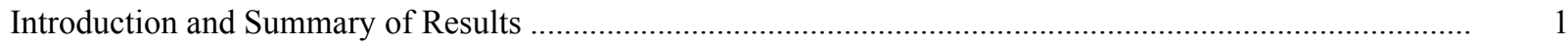

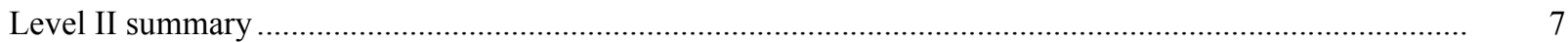

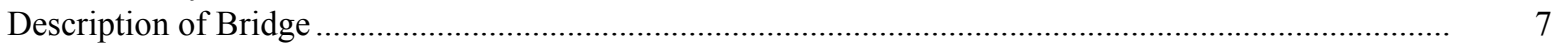

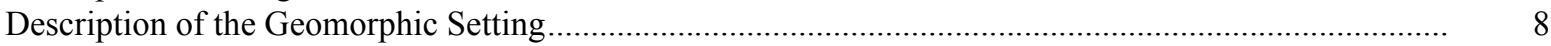

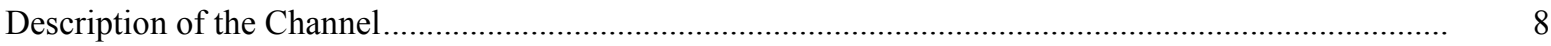

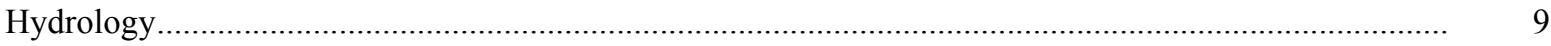

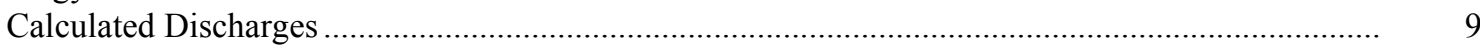

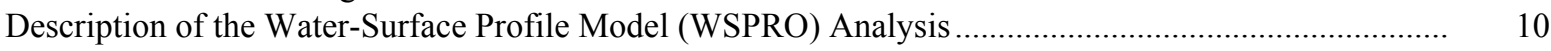

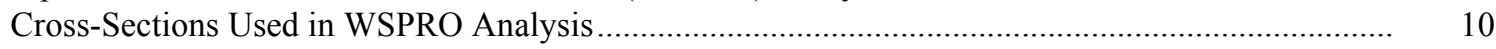

Data and Assumptions Used in WSPRO Model ...................................................................... 11

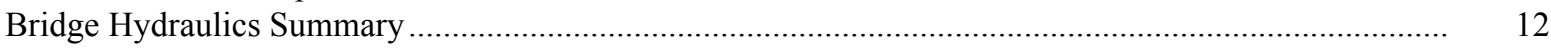

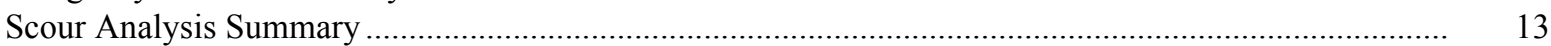

Special Conditions or Assumptions Made in Scour Analysis ...................................................... 13

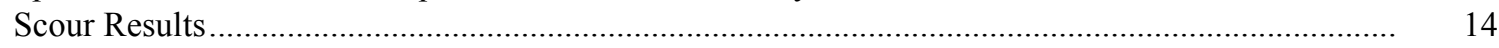

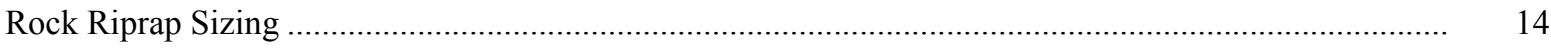

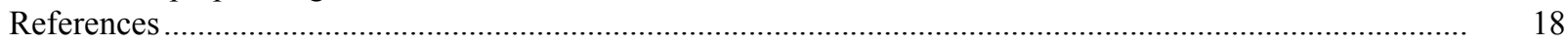

Appendixes:

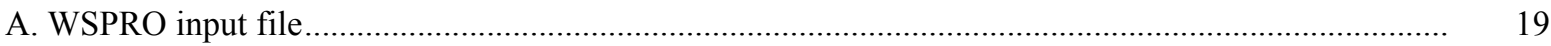

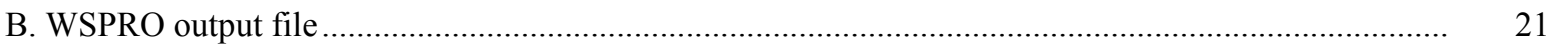

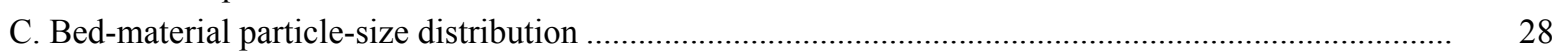

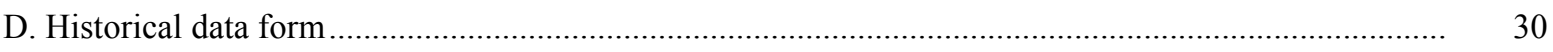

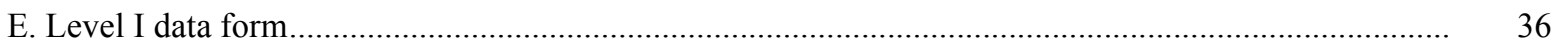

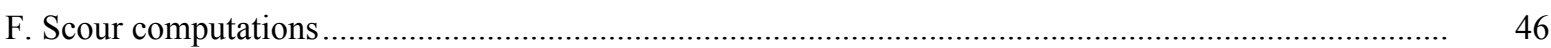

\section{FIGURES}

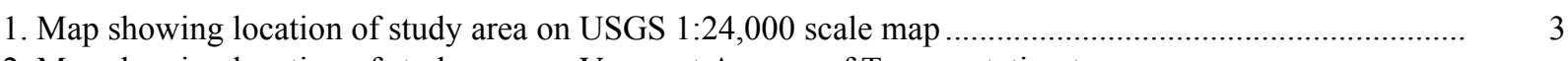

2. Map showing location of study area on Vermont Agency of Transportation town
highway map

3. Structure BRIDTH00460051 viewed from upstream (October 24, 1994) .............................................. 5

4. Downstream channel viewed from structure BRIDTH00460051 (October 24, 1994) ........................... 5

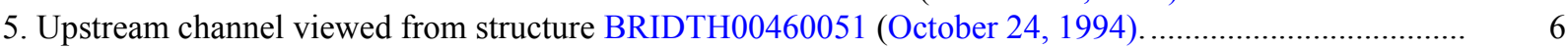

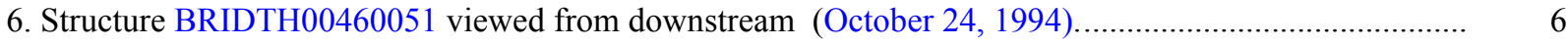

7. Water-surface profiles for the 100- and 500-year discharges at structure

BRIDTH00460051 on Town Highway 46, crossing Ottauquechee River,

Bridgewater, Vermont.

8. Scour elevations for the 100- and 500-year discharges at structure

BRIDTH00460051 on Town Highway 46, crossing Ottauquechee River,

Bridgewater, Vermont.

\section{TABLES}

1. Remaining footing/pile depth at abutments for the 100-year discharge at structure BRIDTH00460051 on Town Highway 46, crossing Ottauquechee River,

Bridgewater, Vermont.

2. Remaining footing/pile depth at abutments for the 500-year discharge at structure

BRIDTH00460051 on Town Highway 46, crossing Ottauquechee River,

Bridgewater, Vermont.

5




\begin{tabular}{|c|c|c|}
\hline Multiply & By & To obtain \\
\hline \multicolumn{3}{|c|}{ Length } \\
\hline inch (in.) & 25.4 & millimeter (mm) \\
\hline foot $(\mathrm{ft})$ & 0.3048 & $\operatorname{meter}(\mathrm{m})$ \\
\hline mile (mi) & 1.609 & kilometer (km) \\
\hline \multicolumn{3}{|c|}{ Slope } \\
\hline foot per mile ( $\mathrm{ft} / \mathrm{mi})$ & 0.1894 & meter per kilometer $(\mathrm{m} / \mathrm{km})$ \\
\hline \multicolumn{3}{|c|}{ Area } \\
\hline square mile $\left(\mathrm{mi}^{2}\right)$ & 2.590 & square kilometer $\left(\mathrm{km}^{2}\right)$ \\
\hline \multicolumn{3}{|c|}{ Volume } \\
\hline cubic foot $\left(\mathrm{ft}^{3}\right)$ & $\begin{array}{l}0.02832 \\
\text { Velocity and Flow }\end{array}$ & cubic meter $\left(\mathrm{m}^{3}\right)$ \\
\hline foot per second $(\mathrm{ft} / \mathrm{s})$ & 0.3048 & meter per second $(\mathrm{m} / \mathrm{s})$ \\
\hline cubic foot per second $\left(\mathrm{ft}^{3} / \mathrm{s}\right)$ & 0.02832 & cubic meter per second $\left(\mathrm{m}^{3} / \mathrm{s}\right)$ \\
\hline $\begin{array}{l}\text { cubic foot per second per } \\
\text { square mile } \\
{\left[\left(\mathrm{ft}^{3} / \mathrm{s}\right) / \mathrm{mi}^{2}\right]}\end{array}$ & 0.01093 & $\begin{array}{l}\text { cubic meter per } \\
\text { second per square } \\
\text { kilometer }\left[\left(\mathrm{m}^{3} / \mathrm{s}\right) / \mathrm{km}^{2}\right]\end{array}$ \\
\hline
\end{tabular}

OTHER ABBREVIATIONS

$\begin{array}{lrlr}\mathrm{BF} & \text { bank full } & \text { LWW } & \text { left wingwall } \\ \mathrm{cfs} & \text { cubic feet per second } & \text { MC } & \text { main channel } \\ \mathrm{D}_{50} & \text { median diameter of bed material } & \text { RAB } & \text { right abutment } \\ \mathrm{DS} & \text { downstream } & \text { RABUT } & \text { face of right abutment } \\ \mathrm{elev} & \text { elevation } & \text { RB } & \text { right bank } \\ \mathrm{f} / \mathrm{p} & \text { flood plain } & \text { ROB } & \text { right overbank } \\ \mathrm{ft} & \text { square feet } & \text { RWW } & \text { right wingwall } \\ \mathrm{ft} / \mathrm{ft} & \text { feet per foot } & \text { TH } & \text { town highway } \\ \mathrm{JCT} & \text { junction } & \text { UB } & \text { under bridge } \\ \mathrm{LAB} & \text { left abutment } & \text { US } & \text { upstream } \\ \mathrm{LABUT} & \text { face of left abutment } & \text { USGS } & \text { United States Geological Survey } \\ \text { LB } & \text { left bank } & \text { VTAOT Vermont Agency of Transportation } \\ \text { LOB } & \text { left overbank } & \text { WSPRO } & \text { water-surface profile model }\end{array}$

In this report, the words "right" and "left" refer to directions that would be reported by an observer facing downstream. Sea level: In this report, "sea level" refers to the National Geodetic Vertical Datum of 1929-- a geodetic datum derived from a general adjustment of the first-order level nets of the United States and Canada, formerly called Sea Level Datum of 1929.

In the appendices, the above abbreviations may be combined. For example, USLB would represent upstream left bank. 


\title{
LEVEL II SCOUR ANALYSIS FOR BRIDGE 51 (BRIDTH00460051) ON TOWN HIGHWAY 46, CROSSING OTTAUQUECHEE RIVER, BRIDGEWATER, VERMONT
}

\author{
By Scott A. Olson and Michael A. Ivanoff
}

\section{INTRODUCTION AND SUMMARY OF RESULTS}

This report provides the results of a detailed Level II analysis of scour potential at structure BRIDTH00460051 on town highway 46 crossing the Ottauquechee River, Bridgewater, Vermont (figures 1-8). A Level II study is a basic engineering analysis of the site, including a quantitative analysis of stream stability and scour (U.S. Department of Transportation, 1993). A Level I study is included in Appendix E of this report. A Level I study provides a qualitative geomorphic characterization of the study site. Information on the bridge available from VTAOT files was compiled prior to conducting Level I and Level II analyses and can be found in Appendix D.

The site is in the Green Mountain physiographic division of central Vermont in the town of Bridgewater. The $103-\mathrm{mi}^{2}$ drainage area is a predominantly rural basin. In the vicinity of the study site, the immediate left and right banks are covered by trees and brush with residences beyond.

In the study area, the Ottauquechee River has a straight channel with a slope of approximately $0.008 \mathrm{ft} / \mathrm{ft}$, an average channel top width of $150 \mathrm{ft}$ and an average channel depth of $6 \mathrm{ft}$. The predominant channel bed materials are gravel and cobble with a median grain size $\left(\mathrm{D}_{50}\right)$ of $81.8 \mathrm{~mm}(0.268 \mathrm{ft})$. The geomorphic assessment at the time of the Level I and Level II site visit on October 24, 1994, indicated that the reach was stable.

The town highway 46 crossing of the Ottauquechee River is a 135-ft-long, two-lane bridge consisting of two 66-ft steel-beam spans, supported by vertical, concrete abutments with upstream wingwalls and one concrete pier (Vermont Agency of Transportation, written commun., August 24, 1994). Type-2 stone fill (less than 36 inches diameter) has been placed along the left abutment and both upstream wingwalls. The upstream side of both road embankments are also protected by type- 2 stone fill. Abutments of a previous bridge still exist at the downstream side of the present structure's abutments. The channel is skewed 10 degrees to the bridge face; the opening-skew-to-roadway is 0 degrees.

There are remains of a breached dam 160 feet upstream of the bridge which deflect flow toward the left bank. Additional details describing conditions at the site are included in the Level II Summary, Appendix D, and Appendix E. 
Scour depths and rock rip-rap sizes were computed using the general guidelines described in Hydraulic Engineering Circular 18 (Richardson and others, 1993). Total scour at a highway crossing is comprised of three components: 1) long-term streambed degradation; 2) contraction scour (due to accelerated flow caused by a reduction in flow area at a bridge) and; 3) local scour (caused by accelerated flow around piers and abutments). Total scour is the sum of the three components. Equations are available to compute depths for contraction and local scour and a summary of the results of these computations follows.

Contraction scour for all modelled flows ranged from 2.6 to $5.4 \mathrm{ft}$. The worst-case contraction scour occurred at the incipient overtopping discharge, which was between the 100- and 500-year discharges. Pier scour ranged from 9.9 to $10.9 \mathrm{ft}$ with the worst-case scenario also occurring at the incipient roadway overtopping discharge. Abutment scour ranged from 25.3 to $33.6 \mathrm{ft}$. with the worst-case occurring at the 500-year discharge. Additional information on scour depths and depths to armoring are included in the section titled "Scour Results". Scoured-streambed elevations, based on the calculated scour depths, are presented in tables 1 and 2. A cross-section of the scour computed at the bridge is presented in figure 8 . Scour depths were calculated assuming an infinite depth of erosive material and a homogeneous particle-size distribution.

It is generally accepted that the Froehlich equation (abutment scour) gives "excessively conservative estimates of scour depths" (Richardson and others, 1993, p. 48). Many factors, including historical performance during flood events, the geomorphic assessment, scour protection measures, and the results of the hydraulic analyses, must be considered to properly assess the validity of abutment scour results. Therefore, scour depths adopted by VTAOT may differ from the computed values documented herein, based on the consideration of additional contributing factors and experienced engineering judgement. 


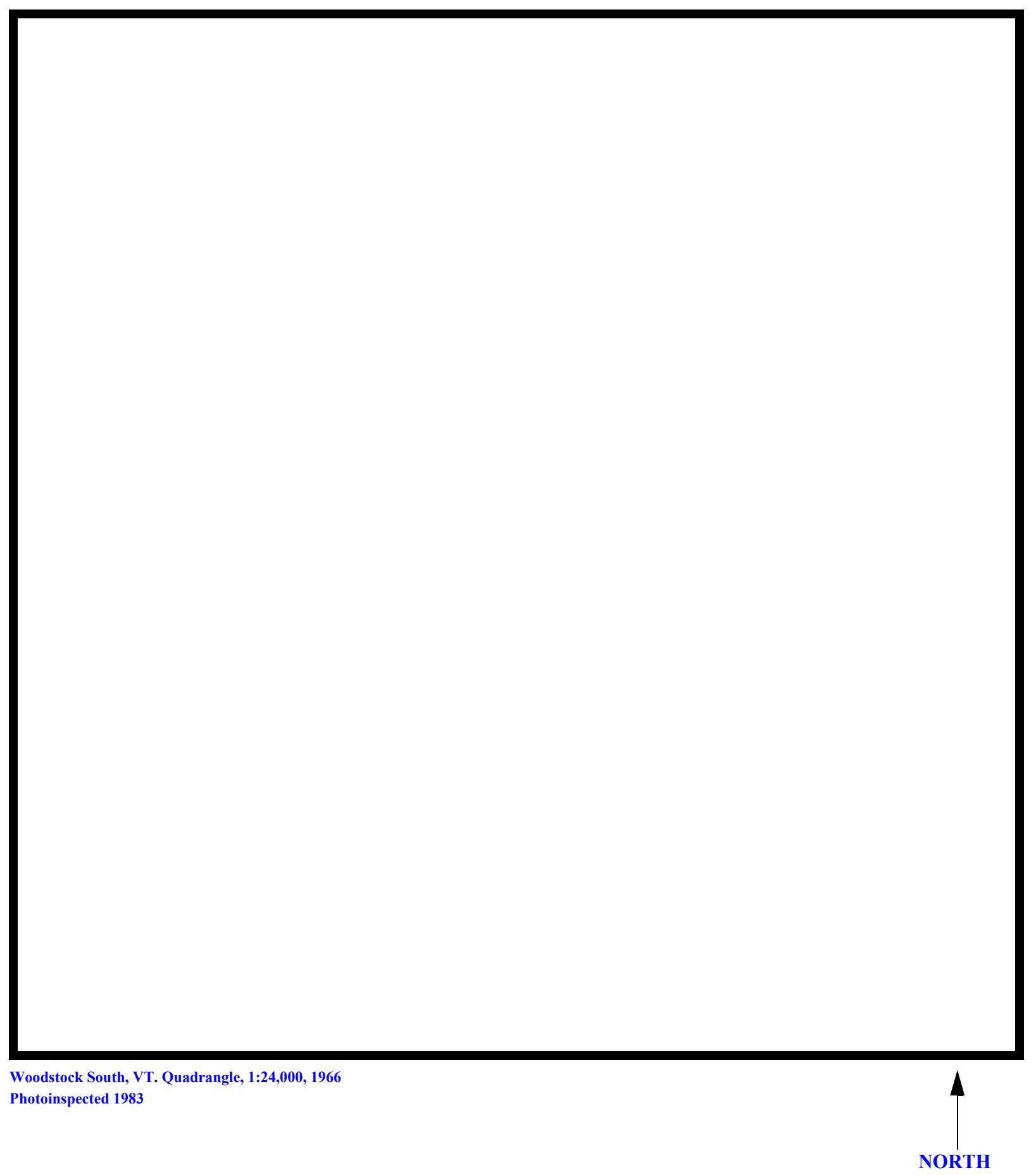

Figure 1. Location of study area on USGS 1:24,000 scale map. 
Figure 2. Location of study area on Vermont Agency of Transportation town highway map. 

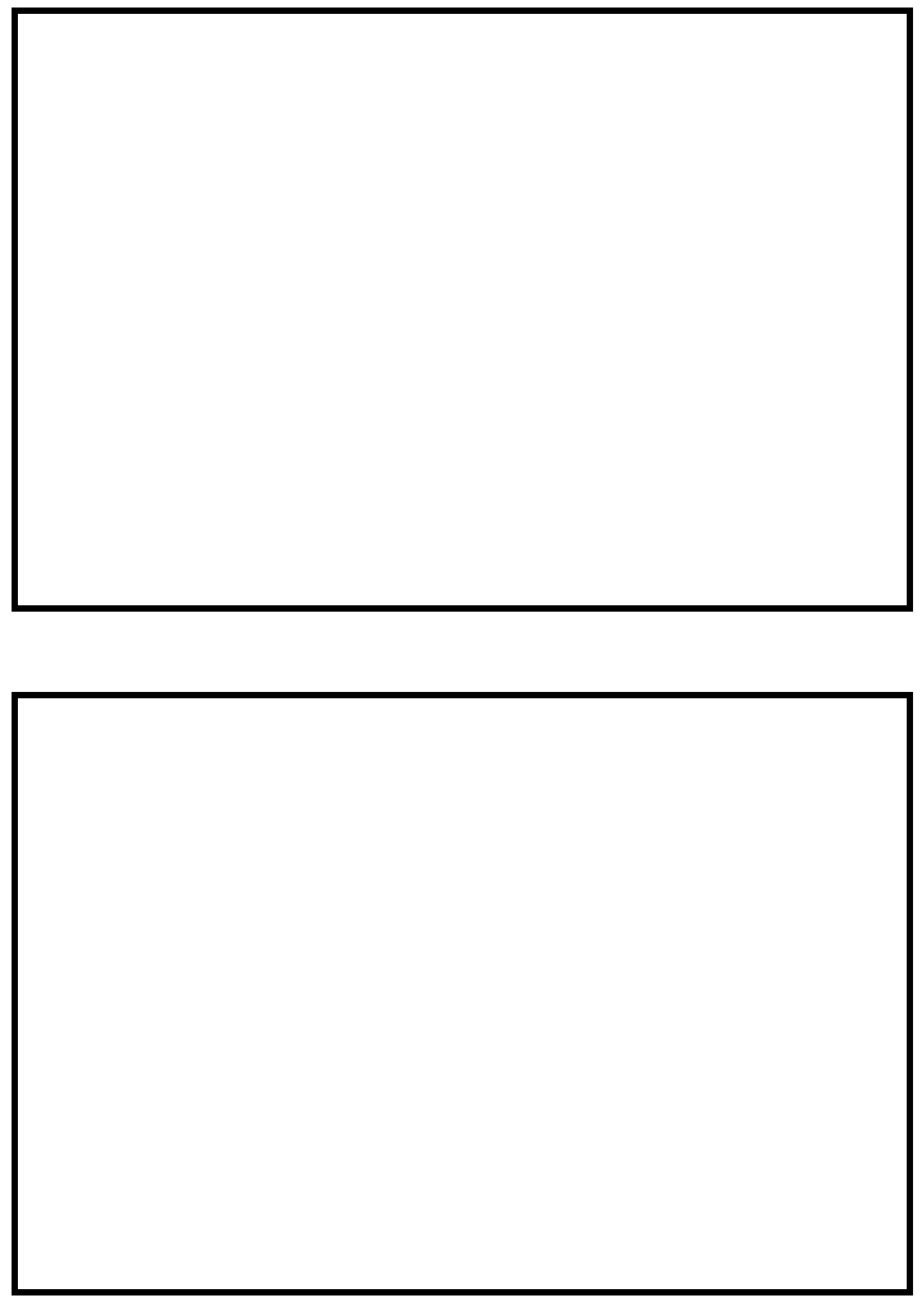

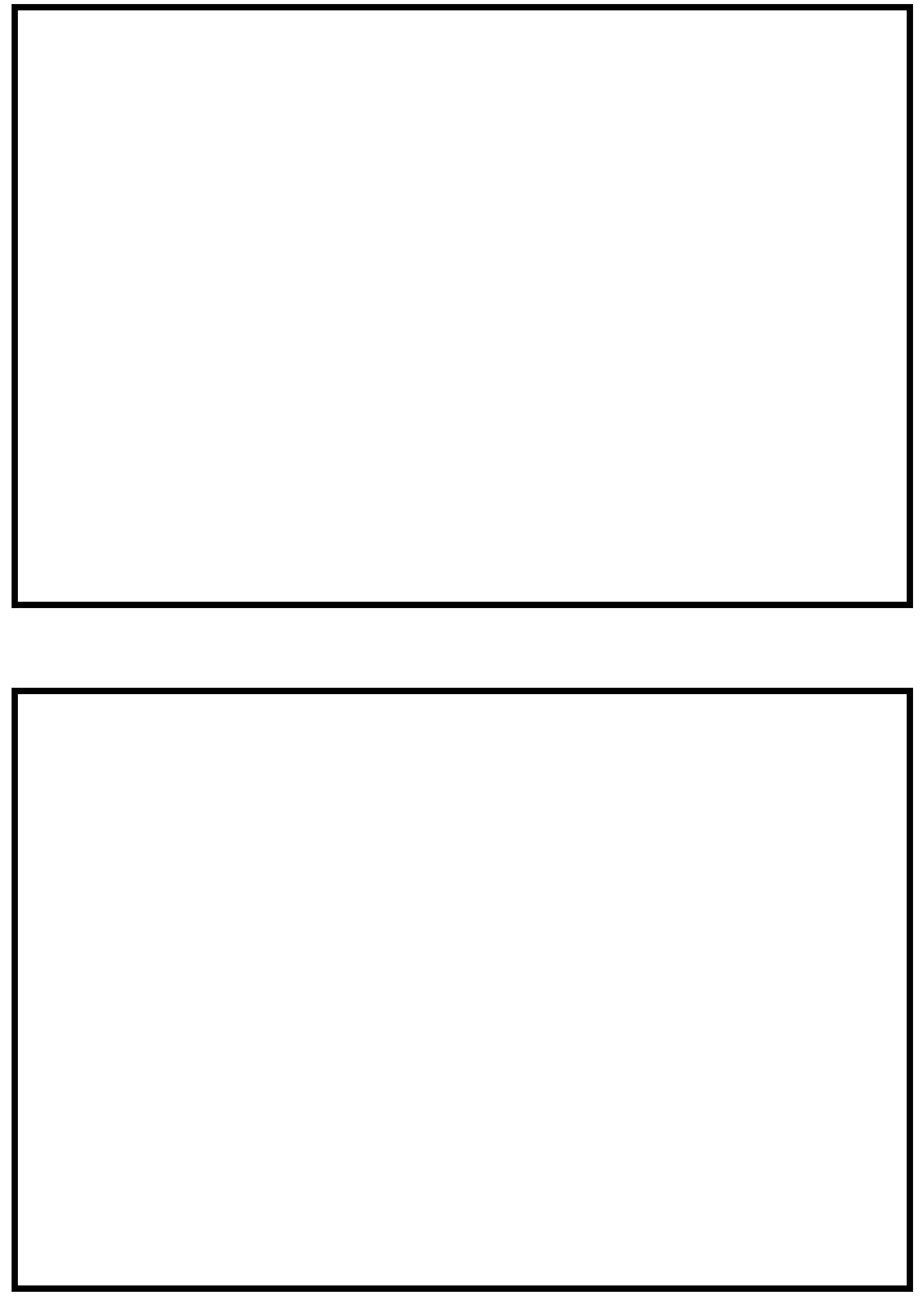


\section{LEVEL II SUMMARY}

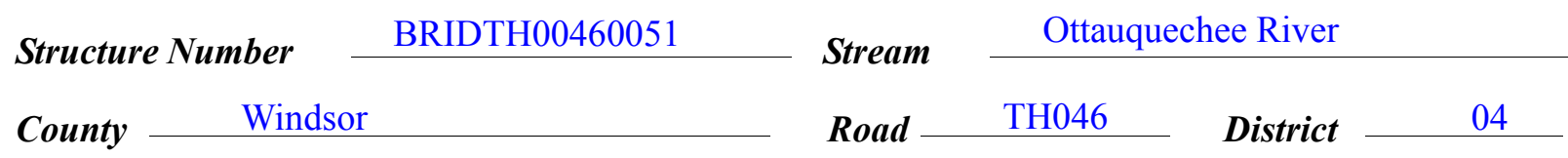

\section{Description of Bridge}

Bridge length $\frac{135}{f t} \quad$ Bridge width $\frac{25.4}{f t}$ Max span length $\frac{66}{f t}$ Alignment of bridge to road (on curve or straight) Abutment type vertical

Stone fill on abutment? yes, left Embankment type sloping straight upstream road embankments.

the downstream side of the abutments are the abutments of a previous structure.

\section{Y}

Is bridge skewed to flood flow according to N_ ' survey?

Angle

The skew is due to the flow being deflected by the breached dam.

Debris accumulation on bridge at time of Level I or Level II site visit:

\begin{tabular}{|c|c|c|c|}
\hline & $\begin{array}{c}\text { Date of insnortion } \\
10 / 24 / 94 \\
\end{array}$ & $\begin{array}{l}\text { Percent of almmust } \\
\text { blocked nortzontatly }\end{array}$ & $\begin{array}{l}\text { Percent of } 0 \\
\text { blocked verticatty }\end{array}$ \\
\hline Level I & $10 / 24 / 94$ & - & - \\
\hline $\begin{array}{l}\text { Level II } \\
\text { breached dam. }\end{array}$ & \multicolumn{3}{|c|}{ Low, although there is some debris caught on the remains of the } \\
\hline
\end{tabular}

October 24, 1994. Remains of a breached dam 160 feet upstream of the bridge deflect flow Doscriho any fonturos noar ar at tho hridos that mav affort flow, (includo ahsorvation dato) toward the left bank. 


\section{Description of the Geomorphic Setting}

General topography At the study site, the channel is incised with narrow floodplains in a moderate relief valley.

Geomorphic conditions at bridge site: downstream (DS), upstream (US)

Date of inspection $\quad 10 / 24 / 94$

DS left: $\quad$ Narrow flood plain.

DS right: $\quad$ Steep high bank to a mildly sloping overbank.

US left: $\quad$ Steep high bank to a mildly sloping overbank.

US right: $\quad$ Steep high bank to a mildly sloping overbank.

\section{Description of the Channel}

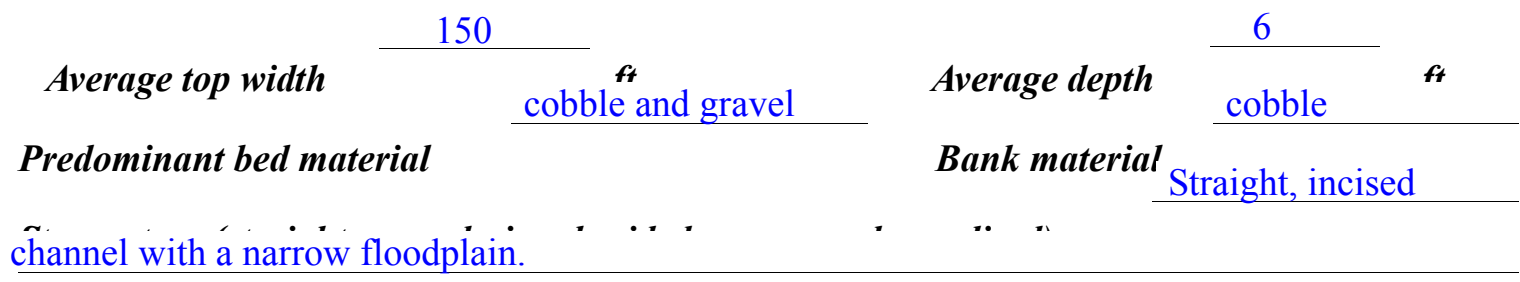

$10 / 24 / 94$

Vegetative $\boldsymbol{c o}^{1}$ Trees and brush; residential on far overbank.

DS left: $\quad$ Moderate tree cover on immediate bank; residential on overbank.

DS right: $\quad$ Moderate tree cover on immediate bank; residential on overbank.

US left: $\quad$ Moderate tree cover.

US right: $\quad \underline{\mathrm{Y}}$

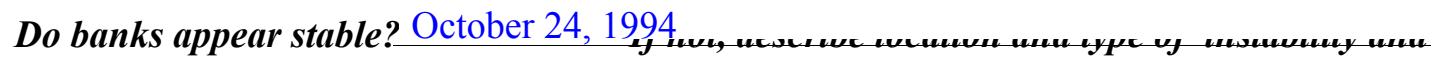

date of observatton.

October 24, 1994.

Remains of a breached dam 160 feet upstream of the bridge deflect flow toward the left bank. Describe any obstructions in channel and date of observation. 


\section{Hydrology}

Drainage area $\frac{103}{\boldsymbol{m i}^{2}}$

Percentage of drainage area in physiographic provinces: (approximate)

Physiographic province

Green Mountain Prov.
Percent of drainage area 100

Is drainage area considered rural or urban? — Rural _ Describe any significant urbanization: None.

Is there a USGS gage on the stream of interest?

No

\section{USGS gage description}

USGS gage number

Gage drainage area

$m i^{2}$

No

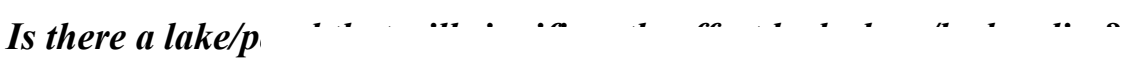

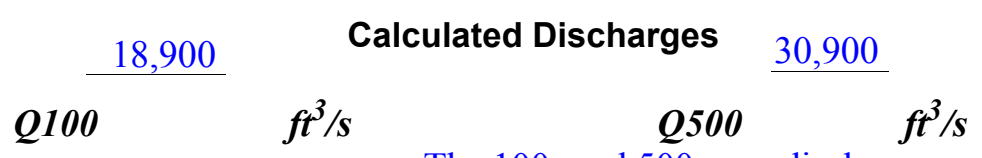

The 100- and 500-year discharges were taken from

the Flood Insurance Study for the Town of Bridgewater (Federal Emergency Management Agency, 1980). 


\section{Description of the Water-Surface Profile Model (WSPRO) Analysis}

Datum for WSPRO analysis (USGS survey, sea level, VTAOT plans)

USGS survey

Datum tie between USGS survey and VTAOT plans

Add $401 \mathrm{ft}$ to USGS survey datum

to get VTAOT datum within one foot. This is also NAVD88.

Description of reference marks used to determine USGS datum. $\quad$ RM1 is the center of a

bronze disk in the top of the downstream end of the right abutment stamped BMN55 (elev.

100.87 feet, arbitrary survey datum). RM2 is a chiseled square on the top of the upstream end of

the left abutment (elev. 101.42 feet, arbitrary survey datum).

\section{Cross-Sections Used in WSPRO Analysis}

\begin{tabular}{cccl}
\hline${ }^{1}$ Cross-section & $\begin{array}{c}\text { Section } \\
\text { Reference } \\
\text { Distance } \\
\text { (SRD) } \text { in feet }\end{array}$ & $\begin{array}{c}{ }^{2} \text { Cross-section } \\
\text { development }\end{array}$ & \multicolumn{1}{c}{ Comments } \\
\hline EXITX & -113 & 1 & $\begin{array}{l}\text { Exit section } \\
\text { Downstream Full-valley } \\
\text { section (Templated from } \\
\text { EXITX) }\end{array}$ \\
FULLV & 0 & 2 & $\begin{array}{l}\text { Bridge section } \\
\text { Road Grade section }\end{array}$ \\
RDWHY & 0 & 1 & $\begin{array}{l}\text { Modelled Approach sec- } \\
\text { tion (Templated from } \\
\text { SURVA) }\end{array}$ \\
APTEM & 13 & 1 & $\begin{array}{l}\text { Approach section as sur- } \\
\text { veyed (Used as a tem- } \\
\text { plate) }\end{array}$ \\
\hline
\end{tabular}

${ }^{1}$ For location of cross-sections see plan-view sketch included with Level I field form, Appendix E. For more detail on how cross-sections were developed see WSPRO input file. 


\section{Data and Assumptions Used in WSPRO Model}

Hydraulic analyses of the reach were done by use of the Federal Highway Administration's WSPRO step-backwater computer program (Shearman and others, 1986, and Shearman, 1990). The analysis reported herein reflects conditions existing at the site at the time of the study. Furthermore, in the development of the model it was necessary to assume no accumulation of debris or ice at the site. Results of the hydraulic model are presented in the Bridge Hydraulic Summary, Appendix B, and figure 7.

Channel roughness factors (Manning's " $n$ ") used in the hydraulic model were estimated using field inspections at each cross section following the general guidelines described by Arcement, Jr. and Schneider (1989). Final adjustments to the values were made during the modelling of the reach. Channel " $\mathrm{n}$ " values for the reach ranged from 0.037 to 0.040 , and overbank " $\mathrm{n}$ " values ranged from 0.075 to 0.085 .

Normal depth at the exit section (EXITX) was assumed as the starting water surface. This depth was computed by use of the slope-conveyance method outlined in the User's manual for WSPRO (Shearman, 1990). The slope used was $0.008 \mathrm{ft} / \mathrm{ft}$ which was determined by an analysis of surveyed thalweg and water-surface points downstream of the bridge.

The surveyed approach section (SURVA) was moved along the approach channel slope $(0.006 \mathrm{ft} / \mathrm{ft})$ to establish the modelled approach section (APPRO), one bridge length upstream of the upstream face as recommended by Shearman and others (1986). This approach also provides a consistent method for determining scour variables. 


\section{Bridge Hydraulics Summary}

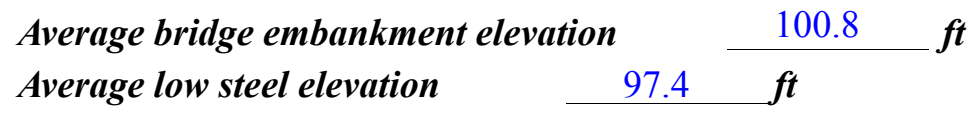

100-year discharge $18,900 \quad \mathrm{ft}^{3} / \mathrm{s}$

Water-surface elevation in bridge opening $\quad \begin{aligned} & 91.9 \quad \boldsymbol{f t} \\ & \end{aligned}$

Road overtopping? ___ N Discharge over road $-{ }^{-}, \ldots$

Area of flow in bridge opening $\quad 1,300 \quad \boldsymbol{f t}^{2}$

Average velocity in bridge opening $\quad \begin{array}{ll}14.5 & f t / s\end{array}$

$\begin{array}{llll}\text { Maximum WSPRO tube velocity at bridge } & 16.2 \mathrm{ft} / \mathrm{s}\end{array}$

Water-surface elevation at Approach section with bridge

Water-surface elevation at Approach section without bridge

95.1

Amount of backwater caused by bridge

$0.1 \quad$ it

500-year discharge $\quad 30,900 \quad \mathrm{ft}^{3} / \mathrm{s}$

Water-surface elevation in bridge opening

$97.4 f t$

Road overtopping? ___ Y Discharge over road _ $4,950 \mathrm{~J} / \mathrm{s}$

Area of flow in bridge opening $\quad 4,530 \quad \mathrm{ft}^{2}$

Average velocity in bridge opening $\quad 13.7 \mathrm{ft} / \mathrm{s}$

Maximum WSPRO tube velocity at bridge 15.1 _s

Water-surface elevation at Approach section with bridge

102.2

Water-surface elevation at Approach section without bridge

Amount of backwater caused by bridge 3.4 .

Incipient overtopping discharge $\quad 24,800 \mathrm{ft}^{3} / \mathrm{s}$

Water-surface elevation in bridge opening $\quad 92.6 \quad t$

Area of flow in bridge opening $\quad 1,390 \quad \mathrm{ft}^{2}$

Average velocity in bridge opening $\quad 17.9 \quad \mathrm{ft} / \mathrm{s}$

Maximum WSPRO tube velocity at bridge $19.8 \mathrm{ft} / \mathrm{s}$

Water-surface elevation at Approach section with bridge

Water-surface elevation at Approach section without bridge

97.7

Amount of backwater caused by bridge

0.7 . $t$ 


\section{Scour Analysis Summary}

\section{Special Conditions or Assumptions Made in Scour Analysis}

Scour depths were computed using the general guidelines described in Hydraulic Engineering Circular 18 (Richardson and others, 1993). Scour depths were calculated assuming an infinite depth of erosive material and a homogeneous particle-size distribution. The results of the scour analysis are presented in tables 1 and 2 and a graph of the scour depths is presented in figure 8 .

The 500-year discharge resulted in unsubmerged orifice flow. Contraction scour at bridges with orifice flow is best estimated by use of the Chang pressure-flow scour equation (oral communication, J. Sterling Jones, October 4, 1996). Therefore, contraction scour for the 500-year discharge was computed by use of the Chang equation (Richardson and others, 1995, p. 145-146). Contraction scour was computed by use of the clear-water contraction scour equation (Richardson and others, 1993, p. 35, equation 18) for the 100-year and incipient road-overflow discharge. For contraction scour computations, the average depth in the contracted section (AREA/TOPWIDTH) is subtracted from the depth of flow computed by the scour equation (Y2) to determine the actual amount of scour. The results of Laursen's clear-water contraction scour for the 500-year event were also computed and can be found in appendix F. The large depth to armoring values indicate that armoring of the channel bed will not limit the amount of contraction scour.

Abutment scour was computed by the Froehlich equation (Richardson and others, 1993, p. 49, equation 24). Parameters for the Froehlich equation include the Froude number of the flow approaching the embankments, the length of the embankment blocking flow, and the depth of flow approaching the embankment less any roadway overtopping.

Pier scour was computed by the Colorado State University (CSU) pier scour equation (Richardson and others, 1993, p. 39, equation 21).

The incipient overtopping model resulted in worst case contraction, abutment, and pier scour. Scour depths for the incipient overtopping model are in the Scour Summary under "other". 


\section{Scour Results}

$$
\text { 100-yr discharge 500-yr discharge }
$$

Contraction scour:

(Scour depths in feet)

Main channel

Live-bed scour

Clear-water scour

Depth to armoring

Left overbank

Right overbank

Local scour:

Abutment scour

Left abutment

Right abutment

Pier scour

Pier 1

Pier 2

Pier 3

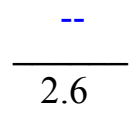

$20.7^{-}$

$--$

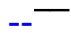

overtopping discharge

Incipient 


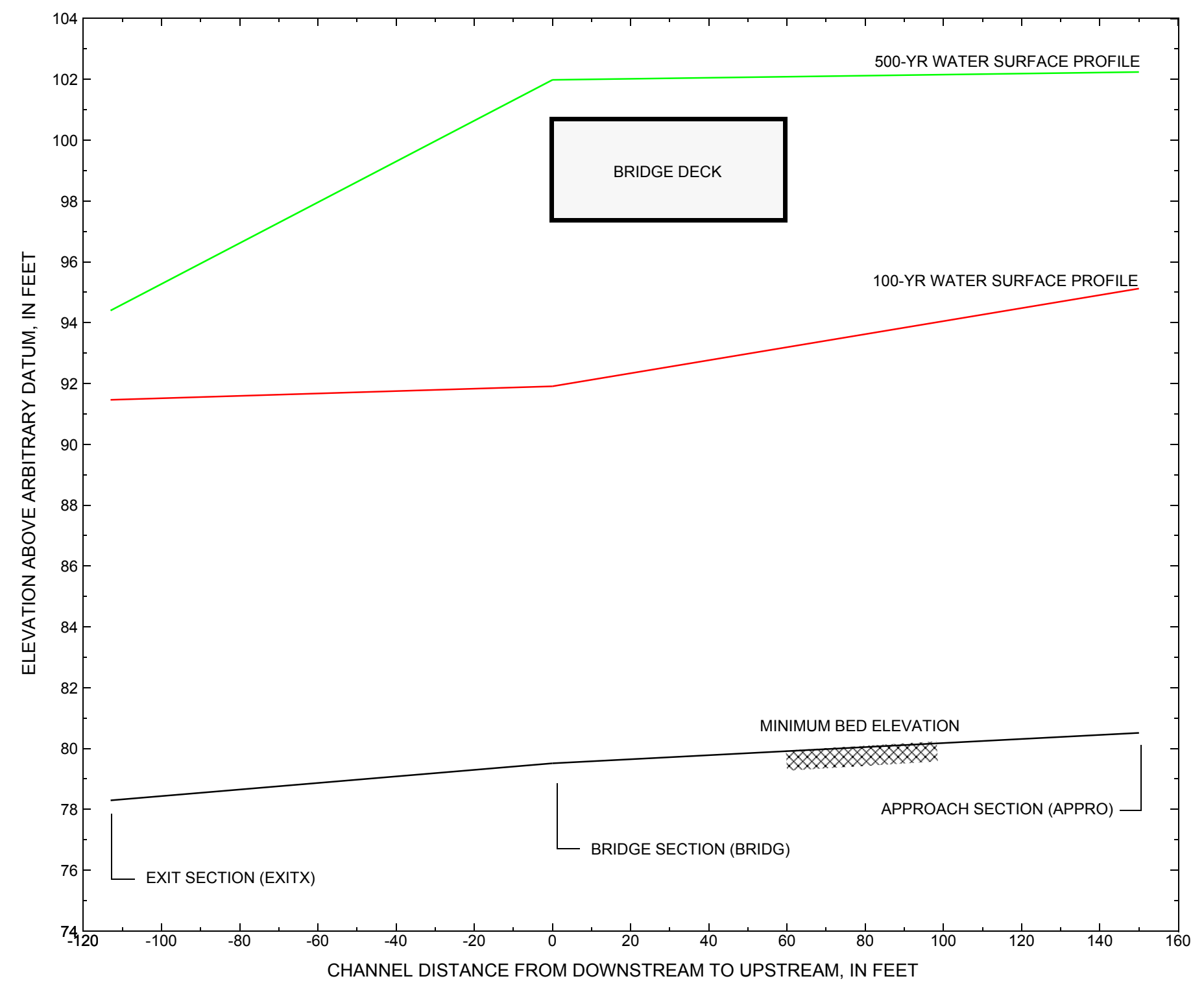

Figure 7. Water-surface profiles for the 100- and 500-yr discharges at structure BRIDTH00460051 on town highway 46, crossing Ottauquechee River, Bridgewater, Vermont. 


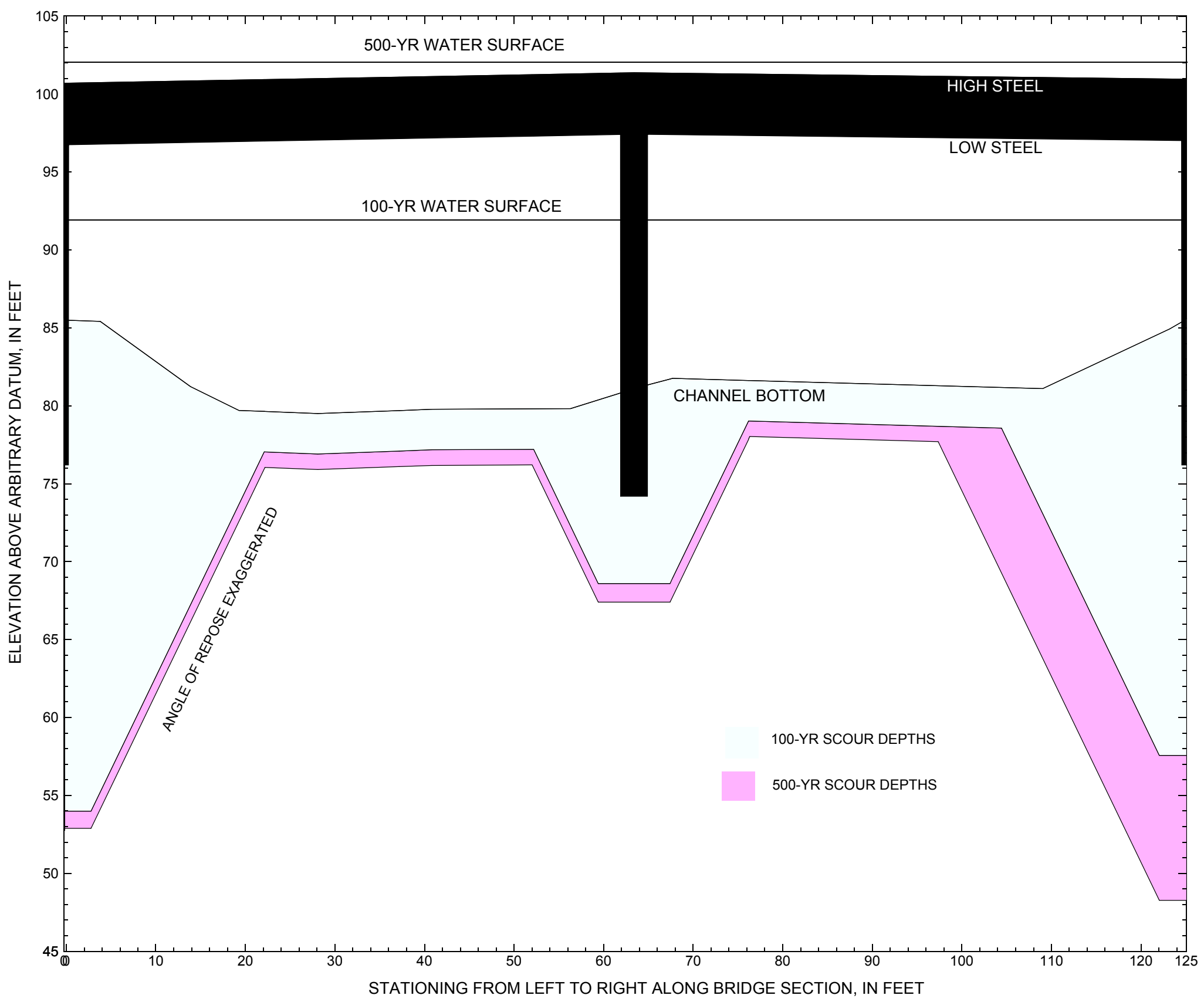

Figure 8. Scour elevations for the 100-yr and 500-yr discharges at structure BRIDTH00460051 on town highway 46, crossing Ottauquechee River, Bridgewater, Vermont. 
Table 1. Remaining footing/pile depth at abutments for the 100-year discharge at structure BRIDTH00460051 on Town Highway 46 , crossing Ottauquechee River, Bridgewater, Vermont.

[VTAOT, Vermont Agency of Transportation; --,no data]

\begin{tabular}{|c|c|c|c|c|c|c|c|c|c|c|c|}
\hline Description & Station $^{1}$ & $\begin{array}{l}\text { VTAOT } \\
\text { plans' } \\
\text { bridge seat } \\
\text { elevation } \\
\text { (feet) }\end{array}$ & $\begin{array}{l}\text { Surveyed } \\
\text { minimum } \\
\text { low-chord } \\
\text { elevation }{ }^{2} \\
\text { (feet) }\end{array}$ & $\begin{array}{l}\text { Bottom of } \\
\text { footing } \\
\text { elevation } \\
\text { (feet) }\end{array}$ & $\begin{array}{c}\text { Channel } \\
\text { elevation at } \\
\text { abutment/ } \\
\text { pier }^{2} \\
\text { (feet) }\end{array}$ & $\begin{array}{l}\text { Contraction } \\
\text { scour depth } \\
\text { (feet) }\end{array}$ & $\begin{array}{l}\text { Abutment } \\
\text { scour } \\
\text { depth } \\
\text { (feet) }\end{array}$ & $\begin{array}{l}\text { Pier } \\
\text { scour } \\
\text { depth } \\
\text { (feet) }\end{array}$ & $\begin{array}{l}\text { Depth of } \\
\text { total scour } \\
\text { (feet) }\end{array}$ & $\begin{array}{c}\text { Elevation of } \\
\text { scour }^{2} \\
\text { (feet) }\end{array}$ & $\begin{array}{c}\text { Remaining } \\
\text { footing/pile } \\
\text { depth } \\
\text { (feet) }\end{array}$ \\
\hline \multicolumn{12}{|c|}{100 -yr. discharge is 18,900 cubic-feet per second } \\
\hline Left abutment & 0.0 & 497.55 & 96.73 & 76 & 85.5 & 2.6 & 28.9 & -- & 31.5 & 54.0 & -22 \\
\hline Pier & 63.4 & 497.90 & 97.43 & 74 & 81.1 & 2.6 & -- & 9.9 & 12.5 & 68.6 & -5 \\
\hline Right abutment & 124.8 & 497.81 & 97.05 & 76 & 85.5 & 2.6 & 25.3 & -- & 27.9 & 57.6 & -18 \\
\hline
\end{tabular}

2. Measured along the face of the most constricting side of the bridge.

2. Arbitrary datum for this study.

Table 2. Remaining footing/pile depth at abutments for the 500-year discharge at structure BRIDTH00460051 on Town Highway 46, crossing Ottauquechee River, Bridgewater, Vermont.

[VTAOT, Vermont Agency of Transportation; --, no data]

\begin{tabular}{|c|c|c|c|c|c|c|c|c|c|c|c|}
\hline Description & Station $^{1}$ & $\begin{array}{l}\text { VTAOT } \\
\text { plans' } \\
\text { bridge seat } \\
\text { elevation } \\
\text { (feet) }\end{array}$ & $\begin{array}{l}\text { Surveyed } \\
\text { minimum } \\
\text { low-chord } \\
\text { elevation } \\
\text { (feet) }\end{array}$ & $\begin{array}{l}\text { Bottom of } \\
\text { footing } \\
\text { elevation } \\
\text { (feet) }\end{array}$ & $\begin{array}{c}\text { Channel } \\
\text { elevation at } \\
\text { abutment/ } \\
\text { pier }^{2} \\
\text { (feet) }\end{array}$ & $\begin{array}{l}\text { Contraction } \\
\text { scour depth } \\
\text { (feet) }\end{array}$ & $\begin{array}{l}\text { Abutment } \\
\text { scour } \\
\text { depth } \\
\text { (feet) }\end{array}$ & $\begin{array}{l}\text { Pier } \\
\text { scour } \\
\text { depth } \\
\text { (feet) }\end{array}$ & $\begin{array}{l}\text { Depth of } \\
\text { total scour } \\
\text { (feet) }\end{array}$ & $\begin{array}{c}\text { Elevation of } \\
\text { scour }^{2} \\
\text { (feet) }\end{array}$ & $\begin{array}{c}\text { Remaining } \\
\text { footing/pile } \\
\text { depth } \\
\text { (feet) }\end{array}$ \\
\hline \multicolumn{12}{|c|}{500 -yr. discharge is 30,900 cubic-feet per second } \\
\hline Left abutment & 0.0 & 497.55 & 96.73 & 76 & 85.5 & 3.6 & 29.0 & -- & 32.6 & 52.9 & -23 \\
\hline Pier & 63.4 & 497.90 & 97.43 & 74 & 81.1 & 3.6 & -- & 10.1 & 13.7 & 67.4 & -7 \\
\hline Right abutment & 124.8 & 497.81 & 97.05 & 76 & 85.5 & 3.6 & 33.6 & -- & 37.2 & 48.3 & -28 \\
\hline
\end{tabular}

1. Measured along the face of the most constricting side of the bridge.

2. Arbitrary datum for this study. 


\section{SELECTED REFERENCES}

Arcement, G.J., Jr., and Schneider, V.R., 1989, Guide for selecting Manning's roughness coefficients for natural channels and flood plains: U.S. Geological Survey Water-Supply Paper 2339, 38 p.

Barnes, H.H., Jr., 1967, Roughness characteristics of natural channels: U.S. Geological Survey Water-Supply Paper 1849, 213 p.

Brown, S.A. and Clyde, E.S., 1989, Design of riprap revetment: Federal Highway Administration Hydraulic Engineering Circular No. 11, Publication FHWA-IP-89-016, 156 p.

Federal Highway Administration, 1983, Runoff estimates for small watersheds and development of sound design: Federal Highway Administration Report FHWA-RD-77-158

Federal Emergency Management Agency, 1980, Flood Insurance Study, Town of Bridgewater, Windsor County, Vermont: Washington, D.C., January 1980.

Froehlich, D.C., 1989, Local scour at bridge abutments in Ports, M.A., ed., Hydraulic Engineering--Proceedings of the 1989 National Conference on Hydraulic Engineering: New York, American Society of Civil Engineers, p. 13-18.

Hayes, D.C.,1993, Site selection and collection of bridge-scour data in Delaware, Maryland, and Virginia: U.S. Geological Survey Water-Resources Investigation Report 93-4017, 23 p.

Interagency Advisory Committee on Water Data, 1982, Guidelines for determining flood flow frequency: U.S. Geological Survey, Bulletin 17B of the Hydrology Subcommittee, 190 p.

Johnson, C.G. and Tasker, G.D.,1974, Progress report on flood magnitude and frequency of Vermont streams: U.S. Geological Survey Open-File Report 74-130, $37 \mathrm{p}$.

Lagasse, P.F., Schall, J.D., Johnson, F., Richardson, E.V., Richardson, J.R., Chang, F., 1991, Stream Stability at Highway Structures: Federal Highway Administration Hydraulic Engineering Circular No. 20, Publication FHWA-IP-90-014, 195 p.

Laursen, E.M., 1960, Scour at bridge crossings: Journal of the Hydraulics Division, American Society of Civil Engineers, v. 86, no. HY2, p. $39-53$.

Potter, W. D., 1957a, Peak rates of runoff in the Adirondack, White Mountains, and Maine woods area, Bureau of Public Roads

Potter, W. D., 1957b, Peak rates of runoff in the New England Hill and Lowland area, Bureau of Public Roads

Richardson, E.V. and Davis, S.R., 1995, Evaluating scour at bridges: Federal Highway Administration Hydraulic Engineering Circular No. 18, Publication FHWA-IP-90-017, 204 p.

Richardson, E.V., Harrison, L.J., Richardson, J.R., and Davis, S.R., 1993, Evaluating scour at bridges: Federal Highway Administration Hydraulic Engineering Circular No. 18, Publication FHWA-IP-90-017, 131 p.

Richardson, E.V., Simons, D.B., and Julien, P.Y., 1990, Highways in the river environment: Federal Highway Administration Publication FHWA-HI90-016.

Ritter, D.F., 1984, Process Geomorphology: W.C. Brown Co., Debuque, Iowa, 603 p.

Shearman, J.O., 1990, User's manual for WSPRO--a computer model for water surface profile computations: Federal Highway Administration Publication FHWA-IP-89-027, 187 p.

Shearman, J.O., Kirby, W.H., Schneider, V.R., and Flippo, H.N., 1986, Bridge waterways analysis model; research report: Federal Highway Administration Publication FHWA-RD-86-108, 112 p.

Talbot, A.N., 1887, The determination of water-way for bridges and culverts.

U.S. Department of Transportation, 1993, Stream stability and scour at highway bridges, Participant Workbook: Federal Highway Administration Publication FHWA HI-91-011.

U.S. Geological Survey, 1966, Woodstock South, Vermont 7.5 Minute Series quadrangle map: U.S. Geological Survey Topographic Maps, Photoinspected 1983, Scale 1:24,000. 


\section{APPENDIX A: \\ WSPRO INPUT FILE}




\section{WSPRO INPUT FILE}

$\mathrm{XT}$

GR

GR

GR

GR

GR

*

AS

GT

$\mathrm{N}$

SA

BP

HP 1 BRIDG

HP 2 BRIDG

HP 1 APPRO

HP 2 APPRO

*

HP 1 BRIDG

HP 2 BRIDG

HP 2 RDWAY

HP 1 APPRO

U.S. GEOLOGICAL SURVEY WSPRO INPUT FILE brid051.wsP CREATED ON 30-AUG-95 FOR BRIDGE BRIDTH00460051 USING FILE brid051.dCa HYDRAULIC ANALYSIS OF BRID051 SAO

* * 0.002

$62930 \quad 552 \quad 553 \quad 551 \quad 5 \quad 16 \quad 17 \quad 13 \quad 3 * \begin{array}{llllllllll}6 & 29 & 14 & 23 & 21 & 11 & 12 & 4 & 7 & 3\end{array}$

189003090024816

$0.008 \quad 0.008 \quad 0.008$

$\operatorname{EXITX}-113$

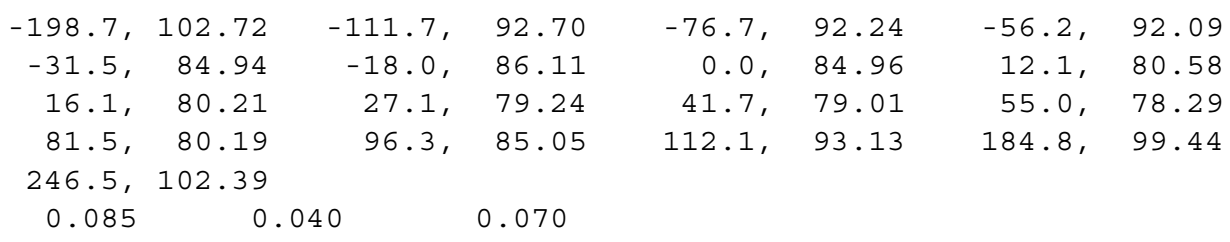




\section{APPENDIX B: \\ WSPRO OUTPUT FILE}


WSPRO OUTPUT FILE

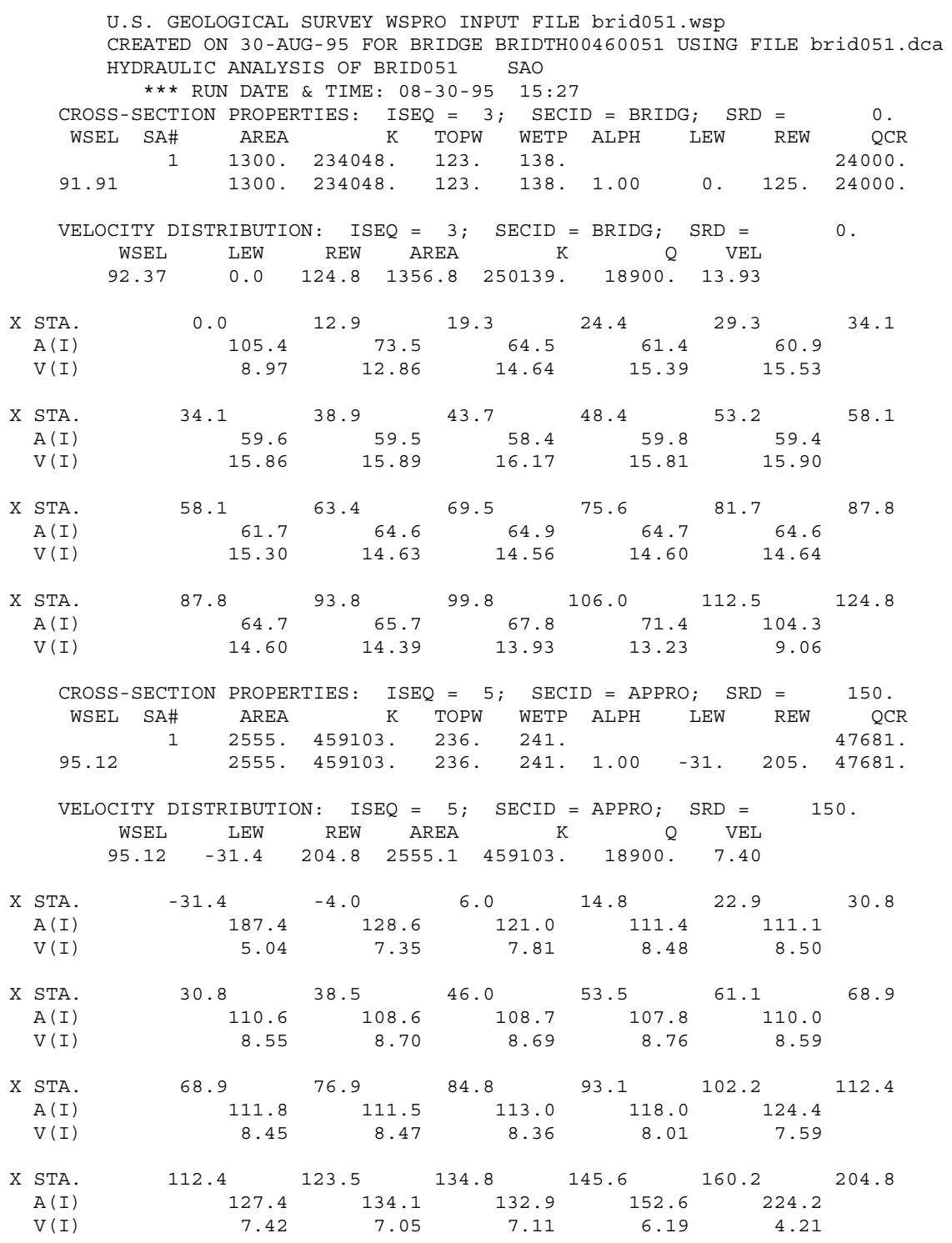


WSPRO OUTPUT FILE (continued)

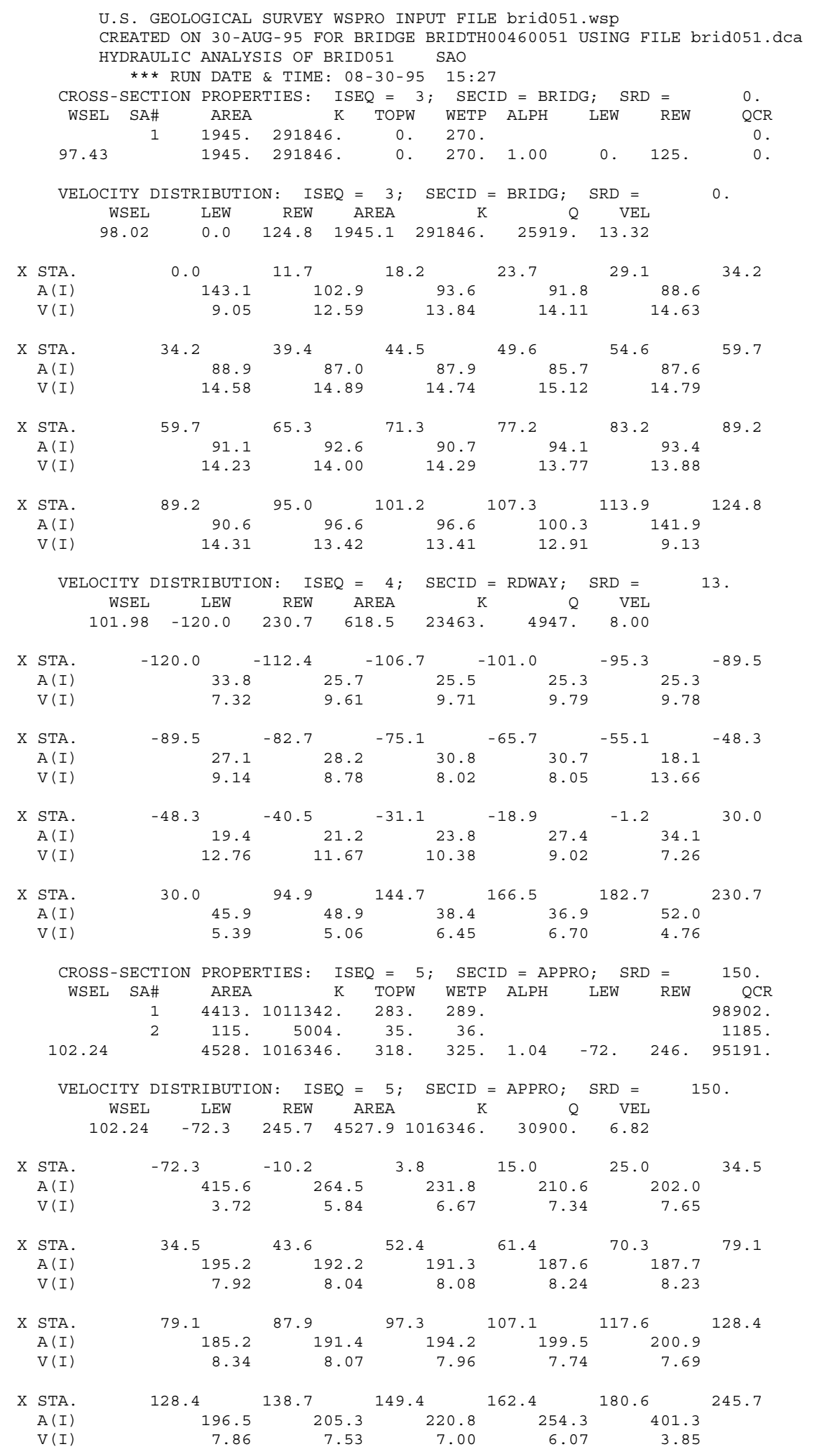


WSPRO OUTPUT FILE (continued)

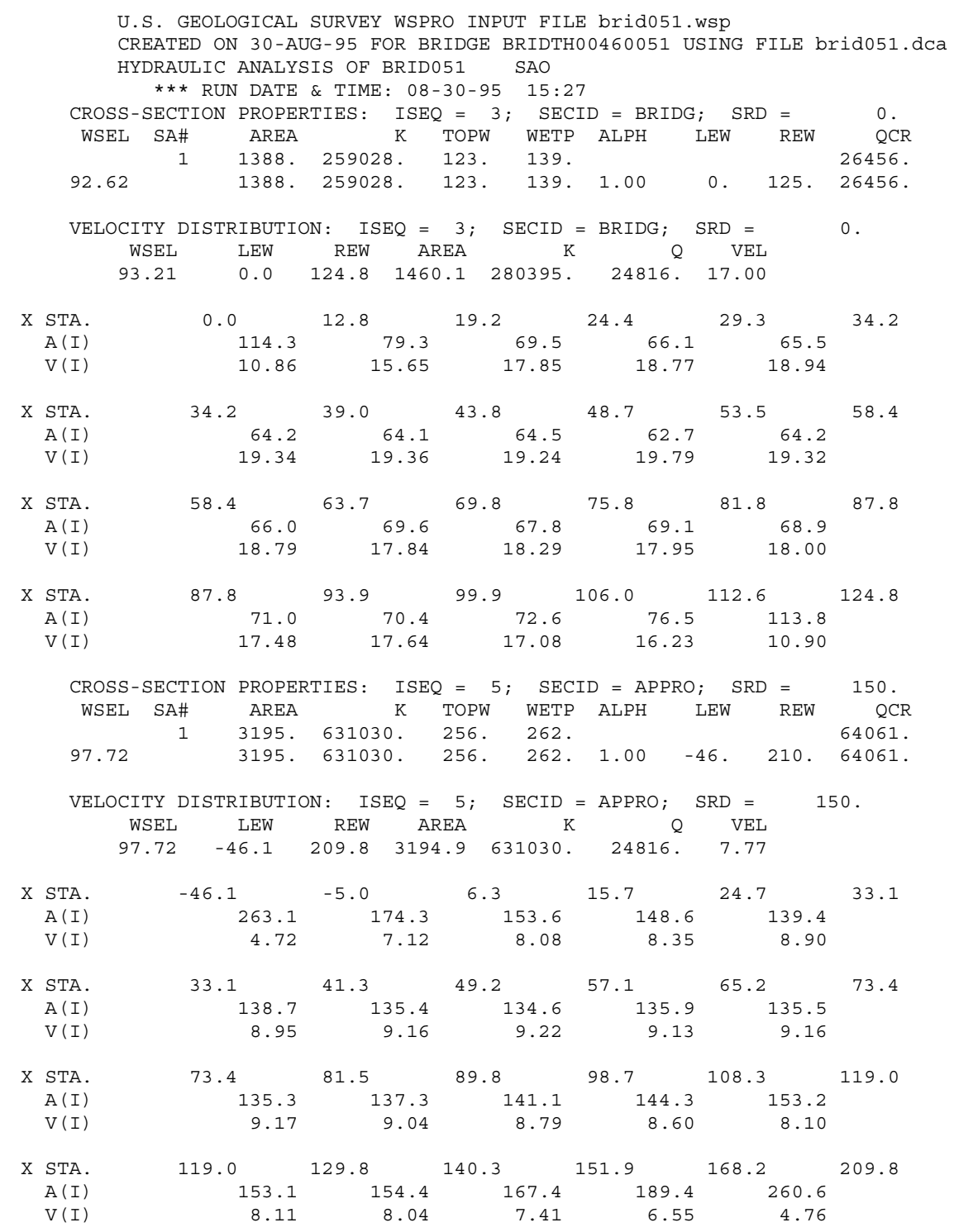


WSPRO OUTPUT FILE (continued)

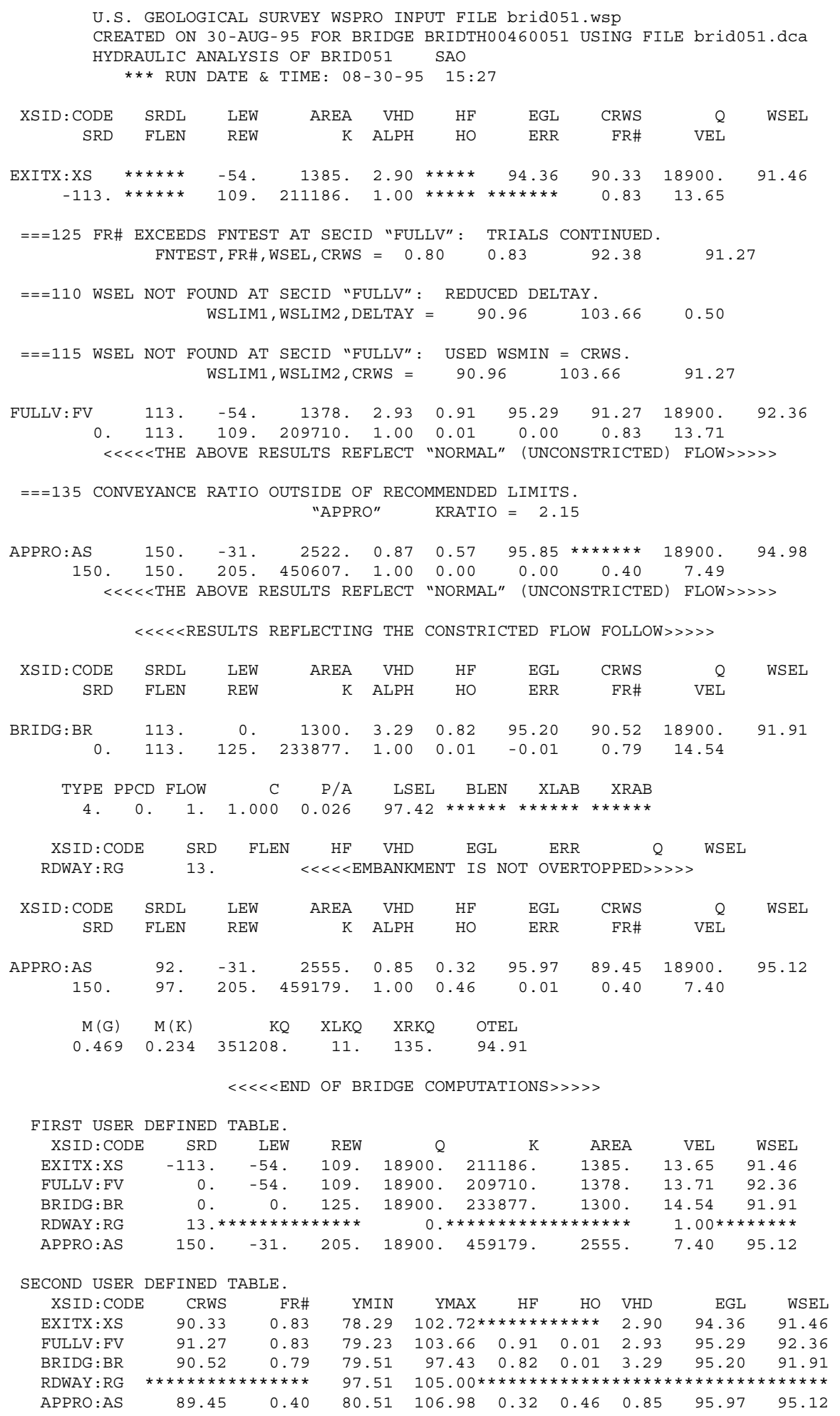


WSPRO OUTPUT FILE (continued)

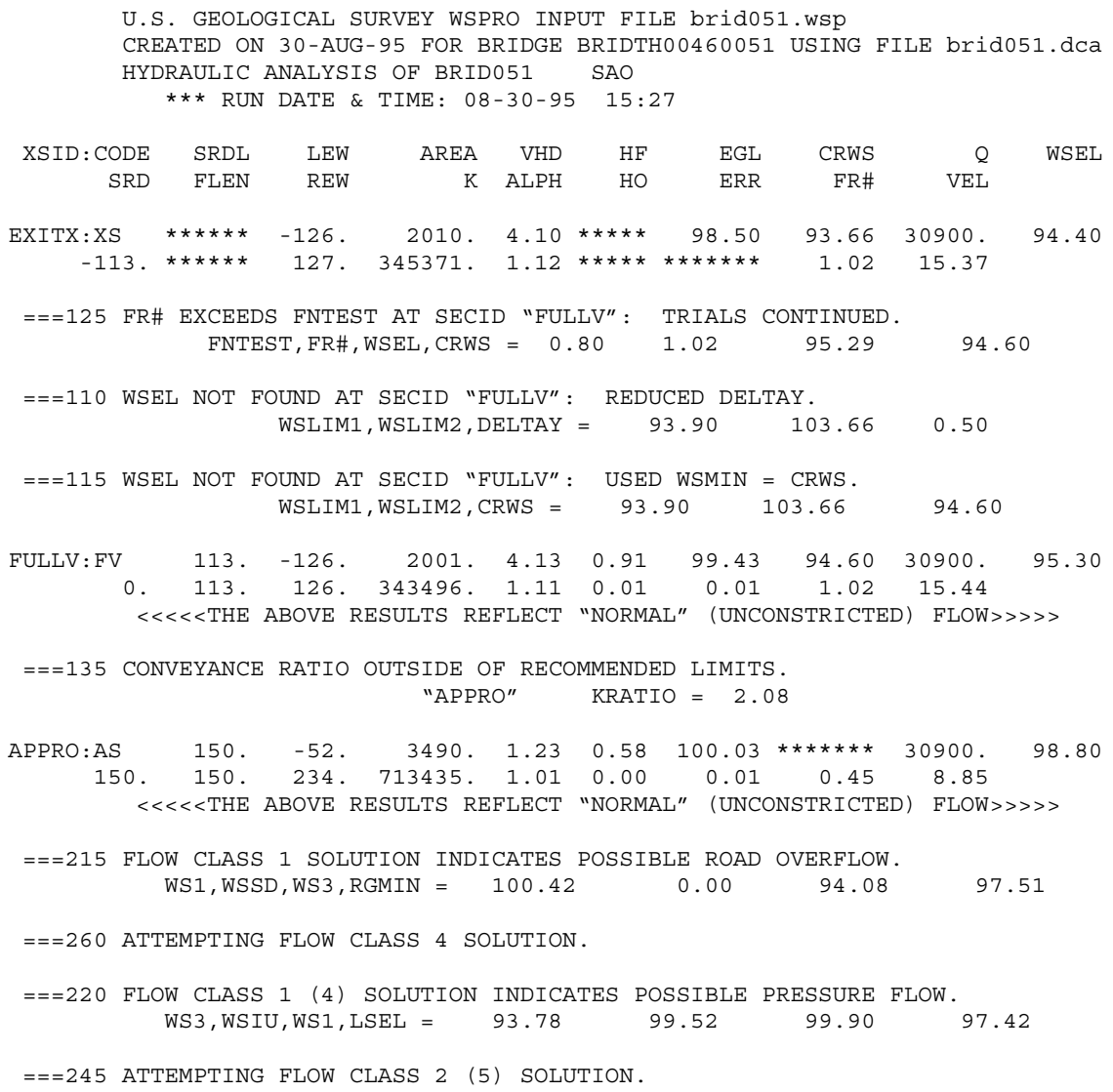

\begin{tabular}{|c|c|c|c|c|c|c|c|c|c|c|c|}
\hline $\begin{array}{l}\text { IRST USER } \\
\text { XSID: CODE }\end{array}$ & $\begin{array}{r}\text { EFINED } \\
\text { SRD }\end{array}$ & LEW & REW & & Q & $\mathrm{K}$ & \multicolumn{2}{|c|}{ AREA } & VEL & \multicolumn{2}{|c|}{ WSEL } \\
\hline EXITX:XS & -113. & -126 & 127. & \multicolumn{2}{|c|}{30900 . } & 5371. & \multicolumn{2}{|c|}{2010.} & 15.37 & \multicolumn{2}{|c|}{94.40} \\
\hline FULLV : FV & 0 . & -126. & 126. & \multicolumn{2}{|c|}{30900 . } & 3496 . & \multicolumn{2}{|c|}{2001.} & 15.44 & \multicolumn{2}{|c|}{95.30} \\
\hline BRIDG : BR & 0 . & 0 . & 125. & \multicolumn{2}{|c|}{25919 . } & 1846. & \multicolumn{2}{|c|}{1895.} & 13.68 & \multicolumn{2}{|c|}{97.43} \\
\hline RDWAY : RG & \multicolumn{2}{|c|}{$13 . * * * * * * *$} & 3357 . & \multirow{2}{*}{\multicolumn{2}{|c|}{$4947 . * * *$}} & \multirow{2}{*}{ 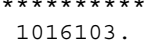 } & $\star \star \star \star \star * *$ & ** & 1.00 & \multicolumn{2}{|c|}{101.98} \\
\hline APPRO : AS & 150. & -72 & 246 & & 900.101 & & \multicolumn{2}{|c|}{4527 . } & 6.83 & \multicolumn{2}{|c|}{102.24} \\
\hline XSID : CODE & CRWS & FR\# & YM & IN & YMAX & $\mathrm{HF}$ & $\mathrm{HO}$ & VHD & & GL & WSEL \\
\hline EXITX:XS & 93.66 & 1.02 & 78. & & 102.72 & 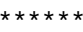 & $\star \star \star \star \star *$ & 4.10 & 98. & 50 & 94.40 \\
\hline FULLV : FV & 94.60 & 1.02 & 79. & & 103.66 & 0.91 & 0.01 & 4.13 & 99. & 43 & 95.30 \\
\hline BRIDG : BR & 92.68 & 0.62 & 79. & & 97.43 & $\star \star \star \star \star * *$ & $\star \star \star \star \star *$ & 2.91 & 100. & 34 & 97.43 \\
\hline RDWAY : RG & 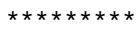 & 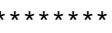 & 97. & & 105.00 & 0.12 * & $\star \star \star \star \star *$ & 0.75 & 102. & & 101.98 \\
\hline APPRO : AS & 92.15 & 0.32 & 80 . & 51 & 106.98 & 0.27 & 0.59 & 0.75 & 102 . & 99 & 102.24 \\
\hline
\end{tabular}


WSPRO OUTPUT FILE (continued)

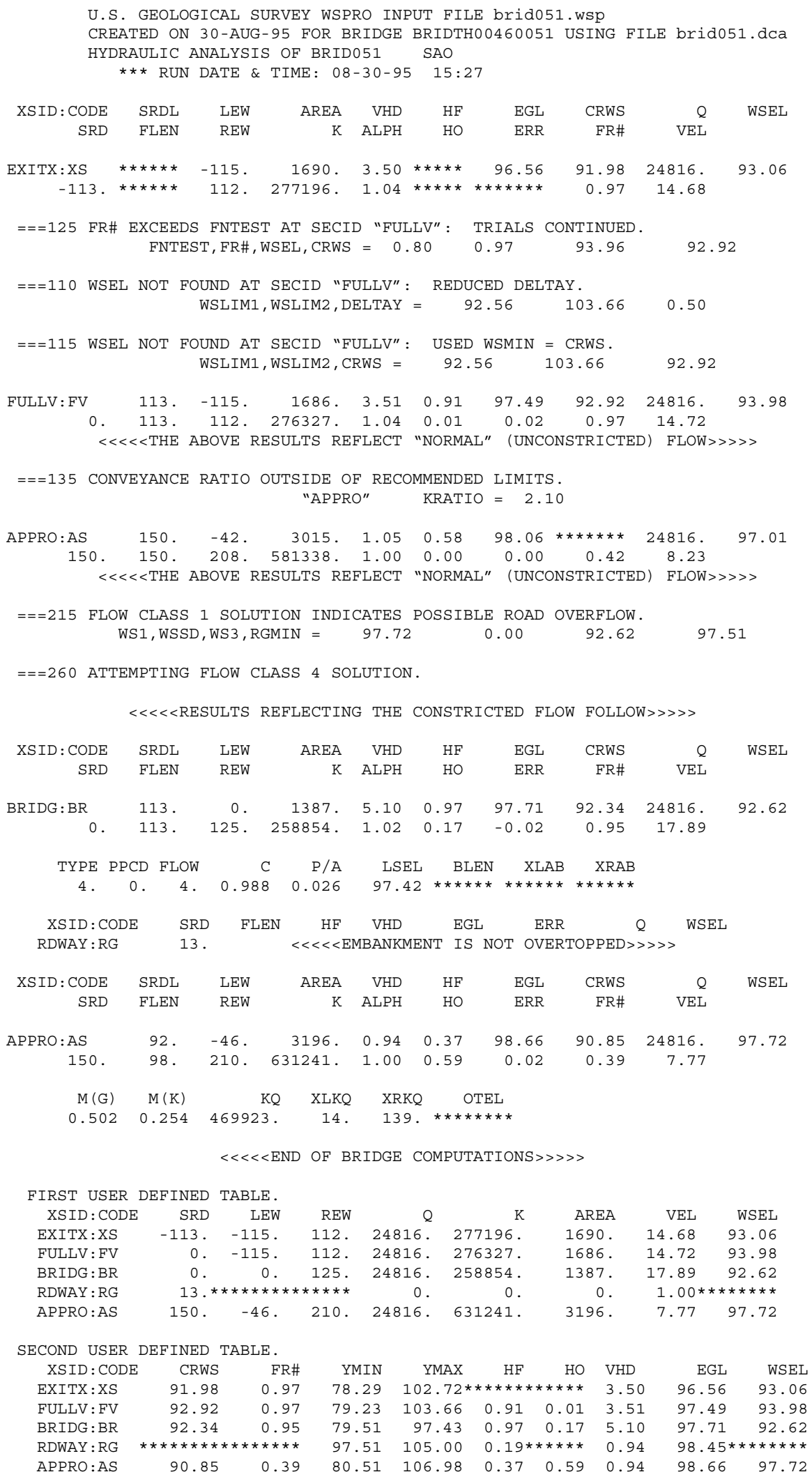




\section{APPENDIX C:}

\section{BED-MATERIAL PARTICAL-SIZE DISTRIBUTION}




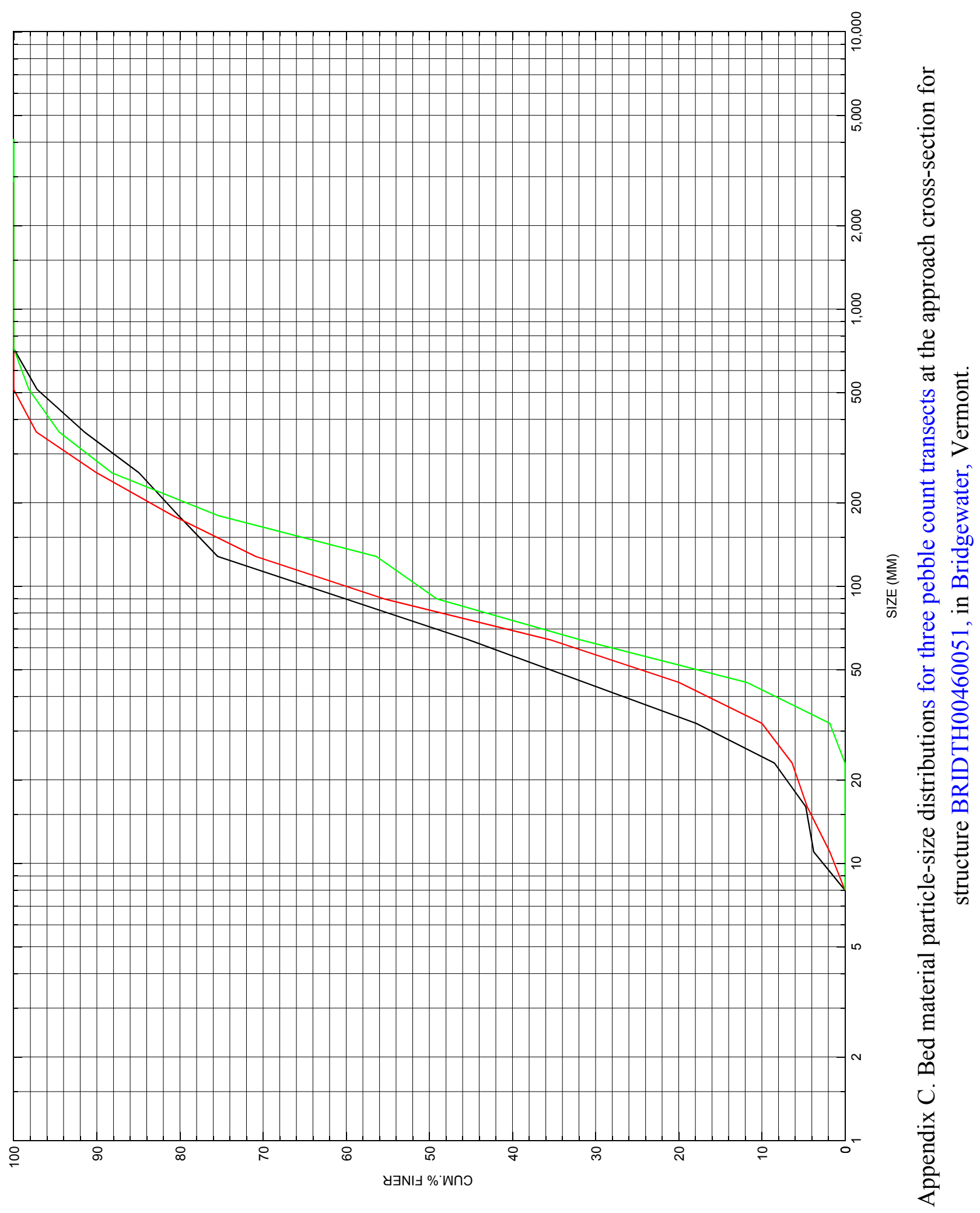




\section{APPENDIX D: \\ HISTORICAL DATA FORM}

